\title{
THE EFFECTIVENESS OF FAMILY PSYCHOLOGICAL TRAINING PROGRAM APPLIED TO RELATIVES OF PATIENTS WITH SCHIZOPHRENIA
}

\author{
Lütfiye Söğütlü̈ ${ }^{1}$, Cenk Varlık ${ }^{2}$, Ahmet Güler ${ }^{3}$, Ylldız Bilge ${ }^{1}$ \& Seyyide Şifa Göktaş ${ }^{1}$ \\ ${ }^{I}$ Department of Psychology, University of Health Sciences, Istanbul, Turkey \\ ${ }^{2}$ Department of Psychiatry, Bakırkoy Research and Training State Hospital, Istanbul, Turkey \\ ${ }^{3}$ Health Directorate of Üsküdar, Addiction Center, Istanbul, Turkey
}

received: 22.2.2021;

revised: 29.4.2021;

accepted: 20.5 .2021

\section{SUMMARY}

Background: The aim of the study is to improve the family relations of the patients who suffer for schizophrenia, to ensure the participation of the family in the treatment, to improve treatment compliance and to reduce relapse.

Subjects and methods: A total of 80 caregivers of the patients, consisting of 40 people as a study group and 40 as a control group, the training was given in two sessions of forty five minutes twice a week, 24 sessions completed in approximately three months. It was applied in both groups at the beginning and end of the training the scales that are the test batteries.

Results: While there was no difference between the two groups according to the pre-test scores obtained before the family psychological training program, according to the post-test scores, there was a significant difference between two groups in terms of symptoms of depression and anxiety, solutionoriented coping, emotion-oriented coping, dangerous perception of the disease and emotion expression.

Conclusion: The training programme thought that the family psychological training support to be given to the relatives of patients with schizophrenia will both contribute positively to the treatment and play an effective role in the adaptation of the caregivers' to the disease.

Key words: the family psychological training program - schizophrenia - caregivers of patients - the burden of care

$$
* * * * *
$$

\section{INTRODUCTION}

According to the World Health Organization (WHO) (2018), schizophrenia is a chronic and serious mental illness affecting more than 21 million people worldwide and is one of the 15 most important causes of disability worldwide (Vos et al. 2017). In schizophrenia due to the skills required for self-care, interpersonal relationships and professional success are highly impaired, most patients spend a significant periods of their lives dependent on their families. After the modulation to a community-based treatment model in schizophrenia, the majority of patients with chronic mental illness started living with their families after acute psychiatric treatment. Therefore, the responsibility of the patients' relatives for the continuation of the treatment has increased gradually (Lauber et al. 2003, Yu et al. 2019).

It is estimated that the rate of living with the families of patients with schizophrenia in our country is more than $95 \%$. It is stated that the most important supporters of patients with schizophrenia when they return to social life after deinstitutionalised are their families and play a more important role in the treatment and adaptation process even than the health care team. Thus, it is stated that it is very important to understand the needs, distress and expectations of patient relatives (Y1ldiz 2000, Yildız 2005, Bustillo et al. 2000, Doğan et al. 2002).
Conducted studies determined that stressful situations which are occured with the aim of caregiving even if the family members were initially healthy, there might be deterioration in their health and functionality in the process (Magliano et al. 2005, Mokwena \& Ngoveni 2020). Although these deteriorations primarily affect the caregivers, it is inevitable that it affects the patients with schizophrenia in the process.

The fact that schizophrenia is a chronic disease creates new and difficult tasks related to caregiving and therefore becomes an objective source of stress for the caregiver, and so adversely affect both the physical and mental health of the caregiver. Anxiety, guilt, anger, stigmatization, loneliness, desperation, frustration are often expressed by many caregivers. They also report mental health problem driven from care. It has been shown an increase in the prevalence of psychiatric morbidity in caregivers of relatives with mental illness, especially depression and anxiety. Comparative studies have shown that depressive symptoms are twice as prevalent in caregivers than in non-caregivers, are more mentally and physically distressed than the same age group, and many are at risk of developing clinical depression without a history of mood disorders (Esther 2003, Heru and Ryan 2002, Shah et al. 2010, Kizilırmak \& Küçük 2016, Fekadu at al. 2019).

Schizophrenia is one of the most burdening mental illnesses for family members. Although the prevalence 
of schizophrenia is relatively low, the burden of disease is quite heavy and caregivers of patients with schizophrenia have been shown to feel more severe burden. In the studies, it was dewelled on various variables that may take the pressure off caregivers burden and many factors related to the patient, the disease and the caregiver were identified. Among the determinants of the caregiver burden, besides the factors related to the patient and the disease, coping skills, beliefs about the disease and expression of emotion have an important place. It is stated that caregivers may feel helpless because of the consequences they are exposed to when they are not aware of how to cope with the illness-related difficulties they face in their daily lives (Gülseren et al. 2010, Maldonado et al. 2005, Ebrahimi et al. 2018, Rahmani et al. 2019).

The information obtained from the conducted studies indicate that the relatives of the patients have negative beliefs, attitudes and stigmatization towards mental illness and affect the patient and the disease in a negative way. It is known that this situation may limit the adaptation of people who have mental illness to join society by creating serious obstacles. Moreover, It is emphasized that high emotion expression is associated with poor clinical course, frequent hospitalizations, frequent repetition, depression and suicide, especially in patients with schizophrenia (Magliano et al. 2005, Sağduyu et al. 2003, Üçok 2007).

It is thought that only medications are inadequate to reduce the symptoms of schizophrenia. In addition to drug treatments, midterm and long term various psychological, social and psychotherapeutic interventions are considered to be beneficial. Especially family members' whose care for the patients faiths about the disease, emotion expression, coping strategies affect their behaviors towards their patients and clinical course of the disease. Since those factors are important It is needed that family mental health education is given to patients in order to treat mental illnesses more effectively and increase the effectiveness of community mental health services.

Among the psychological social approaches used in the treatment of schizophrenic disorders, family psychological education and adjustment therapies are the most commonly used. The purpose of the education of families who have patients with schizophrenia to reduce relapse rates, to improve family functions, to enhance cooperation and treatment compliance (Doğan et al. 2004, Dixon et al. 2004).

In this study, it was objected to consider that whether the variables such as depression, anxiety, caregiving burden, coping, beliefs about mental illness and emotion expression changed or not after the education programme that may occur due to the stress because of being patients' relatives, and this way the aim of this study is to examine the effectiveness of the psychological education program.

\section{SUBJECTS AND METHODS}

\section{Participants}

In this study, a quasi-experimental method consisting of a control group and pre-test and post-test scale was used. Primary caregivers of patients with schizophrenia who were diagnosed with schizophrenia according to DSM-IV and not the first attack, lasted at least one year after diagnosis, were hospitalized at least once and have been treated regularly at Proffessor Dr. Mazhar Osman Mental Health and Neurological Diseases Training and Research Hospital's Küçükçekmece Community Mental Health Center were included to the study. The relatives of the patients who filled informed consent form to participate in the study were considered to be at least primary school graduates, not to have an organic mental disorder or mental retardation, and alcohol or psychoactive substance addiction.

The number of 40 caregivers of patients with schizophrenia who gave consent to participate in the study and those go to the community mental health center regularly were taken as the study group and 40 caregivers of patient with schizophrenia who continued only in the outpatient clinic controls were taken as the control group.

\section{Research Tools}

\section{Sociodemographic Data Form}

It is a form that includes sociodemographic data such as age, gender, education level, marital status, working status prepared by the researcher for the relatives of the patients considering the aims of the study.

\section{Beck Depression Inventory (BDI)}

The self-assessment scale developed by Beck (1961) for measuring emotional, cognitive, somatic and motivational symptoms of depression consists of 21 items and each item is scored between $0-3$. The score obtained from the scale varies between 0 to 63 . The Turkish validity and reliability study was conducted by Hisli (1989).

\section{Beck Anxiety Inventory (BAI)}

This is a 21-item self-assessment scale developed by Beck et al. (1988) to determine the frequency of anxiety symptoms. In the Likert-type scale, which is scored between 0 to 3 , the total score ranges from 0 to 63 , and the high score indicates the high level of anxiety experienced by the individual.

\section{Coping with Stressful Situations Inventory Short Form (CISS)}

The scale evaluates the behavior strategies used by the individual under three headings as solution-oriented coping, emotional coping and avoidant coping. A short form of 21 questions was developed by selecting the items with the highest validity for the sub-dimensions, aiming at ease of application from the long form of 48 questions developed by Endler and Parker in 1990. 


\section{Zarit Caregiver Burden Scale (ZCBS)}

The scale developed by Zarit et al. (1985) consists of 22 questions and examines the negative effects of caregiving on physical, mental, social activity and economic resources. The Turkish validity and reliability study of the scale was conducted by Özlü (2009) on a sample of 100 people. The total score ranges from 19 to 95 and the high scale score indicates that the problem encountered is is high.

\section{Beliefs about Mental Illness Scale (BMI)}

It was developed by Hirai and Clum (2000) in order to evaluate beliefs about mental illness and in 2008, Bilge and Çam made Turkish validity and reliability. This 6-point likert scale, consisting of 21 items containing negative beliefs about mental illness, has a score of "completely agree" and "mostly disagree" and has 3 sub-scales which are danger, despair and deterioration in interpersonal relationships. The score that can be obtained from the scale varies between 0 to 105 . A high score on the scale without a cut-off score indicates negative belief.

\section{Emotion Expression Scale (EES)}

It was developed by Cole and Kazarian (1988). The validity and reliability study was conducted by Berksun (1992) and given to relatives of patients with schizophrenia. In our study, total score was studied. Higher scores mean high level of emotion expression.

\section{Process}

Prior to the start of the study Ethics Committee approval was received from Proffessor Dr. Mazhar Osman Mental Health and Neurological Diseases Training and Research Hospital with protocol number 41340010 / 62548-360 dated 02.12.2013. Subsequently, informed consent was signed by the patient's relatives who agreed to participate in the study and were randomly assigned to the study or control group. The number of 40 caregivers of patients with schizophrenia who gave consent to participate in the study and those go to the community mental health center regularly were taken as the study group and 40 caregivers of patient with schizophrenia who continued only in the outpatient clinic controls were taken as the control group.

\section{Interventions}

The study program was divided into two groups and the training program which was prepared for both groups was given in 24 sessions as two forty-five minutes twice a week for 12 weeks between February and April 2016 and completed in approximately three months. The psychological education program was conducted by a multidisciplinary team of four to six members: psychiatrists, clinical psychologists, psychiatric nurses. The test battery was applied by the researcher individually to the relatives of the patients in the two groups at the beginning and end of the training. Test battery was applied to the patient relatives in the control group on the same dates as the training group. The family psychological education program is shaped according to the current needs of the families and the literature (Anderson et al. 1986, Stengard 2003, Muesser \& Glynn 1999). The subtitles of the mental education given to the participants are: definition of psychosis, etiology, symptoms of schizophrenia, living with hallucinations and delusions, the correct use of medicines and non-organic interventions, drug side effects, preliminary symptoms, relapse of the disease, the role of treatment in the prevention of relapse, recognizing and coping with persistent symptoms, coping strategies with schizophrenia, review of available social support and services.

\section{Analysing of Data}

First of all, Pearson Correlation Coefficient was calculated to determine the correlations between the scores of the whole group. Descriptive statistics related to the scores of the scales used in the study are presented as mean and standard deviation. To evaluate the difference intergroups Mann-Whitney $U$ and ingroups Wilcoxon Sign tests were used, since the groups did not show a normal distribution in the comparison of the scores of the scales applied before and after the mental training program. SPSS 20 program was used for statistical analysis and statistical significance was accepted as the level of significance $(\mathrm{p}=0.05)$.

\section{RESULTS}

\section{Sociodemographic Data Results}

When the sociodemographic datas of the participants were examined, the participants in the study group, in terms of gender features, 30 female $(75 \%)$ and $10(25 \%)$ male; in terms of age, 10 people $(25 \%)$ between the age of $22-45,16$ people ( $40 \%$ ) between the age of $46-60$ and 14 people (35\%) 61-75; in terms of educational background, 34 people $(85 \%)$ primary school graduates, 4 people $(10 \%)$ high school graduates and 2 person (5\%) university graduates; and in terms of intimacy degree 18 people $(45 \%)$ mothers, 10 people $(25 \%)$ fathers, 4 people $(10 \%)$ siblings and 8 people $(20 \%)$ spouses listed. On the other hand, the participants in the control group, in terms of gender features, 22 people $(55 \%)$ female and 18 people $(45 \%)$ male; in terms of age; 14 people $(35 \%)$ were in the $22-45$ age range, 16 people $(40 \%)$ were in the $46-60$ age range, and 10 people (25\%) were in the 61-71 age range; in terms educational background, 26 people $(65 \%)$ primary school graduates, 10 people $(25 \%)$ high school graduates and 4 people $(10 \%)$ university graduates; and in terms of intimacy degree 20 people $(50 \%)$ mothers, 12 people $(30 \%)$ fathers and 8 people $(20 \%)$ spouses listed. 


\section{CORRELATION RESULTS}

According to the correlation results between the scales applied to the whole group before starting the study; significant relationships were detected that are medium level of positive correlation between depression symptoms and anxiety symptoms of patient relatives $(\mathrm{r}=0.62, \mathrm{p}=0.000)$, between caregiving burden positively moderate $(\mathrm{r}=0.54, \mathrm{p}=0.000)$, between the solution-oriented coping positively weak $(\mathrm{r}=0.34, \mathrm{p}=0.035)$, between hopelessness and interpersonal relations deterioration positively weak $(r=0.32, p=0.046)$. While there was a significant positively moderate correlation between anxiety symptoms and caregiving burden $(\mathrm{r}=0.59, \mathrm{p}=0.000)$, between caregiving burden and avoidant coping was found to be significant positively weak $(r=0.34$, $\mathrm{p}=0.031)$ also, we found a significant positively week correlation between caregiving and embarrassment of the disease $(\mathrm{r}=0.33, \mathrm{p}=0.037)$. No significant correlation was found between emotion expression and any scale.

\section{Comparison of Study and Control Groups Results}

The family psychological training program was applied to the relatives of the patients and it was carried out on the dates specified by the first researcher. Volunteers who participated in the study completed the study to the end. The attendance rate of the participants is about $75 \%$. According to the results obtained from the analyzes, the mean and standard deviation values of the scores obtained from the pre-test and post-test applications of the participants in the study and control groups are given in Table 1.

When the pre-test and post-test scores of the two groups were compared, the difference between the groups according to the pre-test scores was not significant. According to the post-test scores, there were significant differences between the two groups in terms of symptoms of depression and anxiety, solution- oriented coping, emotion-oriented coping, dangerous perception of the disease and emotion expression. There was not detected significant difference in terms of care burden, avoidant coping, desperation and interpersonal relations deterioration and embarrassment of the disease (Table 2).

When the pre-test and post-test scores of the study and control groups were compared, a significant difference was found between the pre-test and post-test scores of the study group who participated in the family psychological education program in all scale scores except caregiving burden and desperation and interpersonal relations deterioration. In the control group who did not participate in the training program, no significant difference was found between the pretest and post-test scores (Table 3).

Table 1. Arithmetic Mean and Standard Deviation Values of Pre-Test and Post-Test Scores of Study and Control Groups

\begin{tabular}{llrrrr}
\hline \multirow{2}{*}{ Scales } & \multicolumn{3}{c}{ Study Group } & \multicolumn{2}{c}{ Control Group } \\
& & Pre-Test; N=40 & Post-Test; N=40 & Pre-Test; N=40 & Post-Test; N=40 \\
\hline \multirow{2}{*}{ BDI } & M & 22.50 & 12.25 & 22.40 & 21.15 \\
& SD & 9.12 & 7.29 & 7.41 & 8.76 \\
BAI & $\mathrm{M}$ & 14.25 & 8.55 & 14.70 & 14.80 \\
& $\mathrm{SD}$ & 8.97 & 7.32 & 8.12 & 7.74 \\
ZCBS & $\mathrm{M}$ & 53.75 & 54.65 & 54.45 & 55.25 \\
& $\mathrm{SD}$ & 17.65 & 19.93 & 17.80 & 18.42 \\
CISS-21-SOC & $\mathrm{M}$ & 13.95 & 23.65 & 16.55 & 16.25 \\
& $\mathrm{SD}$ & 5.71 & 6.43 & 8.33 & 8.12 \\
CISS-21-EOC & $\mathrm{M}$ & 16.40 & 13.40 & 21.15 & 21.70 \\
& $\mathrm{SD}$ & 6.99 & 6.01 & 8.57 & 8.44 \\
CISS-21-AC & $\mathrm{M}$ & 26.65 & 23.20 & 21.35 & 22.35 \\
\multirow{3}{*}{ BMI-D } & $\mathrm{SD}$ & 5.91 & 5.98 & 8.47 & 9.35 \\
& $\mathrm{M}$ & 20.00 & 13.10 & 20.10 & 19.30 \\
BMI-DIRD & $\mathrm{SD}$ & 7.96 & 5.81 & 7.53 & 8.35 \\
\multirow{3}{*}{ BMI-E } & $\mathrm{M}$ & 26.05 & 27.15 & 23.35 & 22.80 \\
& $\mathrm{SD}$ & 10.27 & 8.93 & 9.24 & 9.32 \\
EES & $\mathrm{M}$ & 23.30 & 20.30 & 25.00 & 24.45 \\
& $\mathrm{SD}$ & 7.55 & 6.25 & 9.61 & 9.20 \\
& $\mathrm{M}$ & 16.10 & 11.80 & 18.55 & 19.10 \\
& $\mathrm{SD}$ & 6.09 & 4.29 & 7.04 & 7.15 \\
\hline
\end{tabular}

BDI: Beck Depression Inventory; BAI: Beck Anxiety Inventory; ZCBS: Zarit Care Burden Scale; CISS-21-SOC: The Coping Inventory for Stressful Situations, Solution-oriented Coping; CISS-21-EOC: The Coping Inventory for Stressful SituationsEmotion-oriented Coping; CISS-21-AC: The Coping Inventory for Stressful Situations -Avoidant Coping; BMI-D: Beliefs Toward Mental Illness Scale-Danger; BMI-DIRD: Beliefs Toward Mental Illness Scale- Desperation and Interpersonal Relations Deterioration; BMI-E: Beliefs Toward Mental Illness Scale- Embarrassment; EES: Expressed Emotion Scale 
Table 2. Results of Comparison of Pre-Test and Post-Test Scores of Study and Control Groups According to Scales

\begin{tabular}{|c|c|c|c|c|c|}
\hline \multirow{2}{*}{ Scales } & \multirow{2}{*}{$\begin{array}{l}\text { Groups } \\
\mathrm{N}=40+40\end{array}$} & \multicolumn{2}{|c|}{ Pre-Test Scales } & \multicolumn{2}{|c|}{ Post-Test Scales } \\
\hline & & $\mathrm{Z}$ & $\mathrm{p}$ & $\mathrm{Z}$ & $\mathrm{p}$ \\
\hline BDI & $\begin{array}{l}\text { Study } \\
\text { Control }\end{array}$ & -0.298 & 0.779 & -2.878 & 0.004 \\
\hline BAI & $\begin{array}{l}\text { Study } \\
\text { Control }\end{array}$ & -0.203 & 0.841 & -2.709 & 0.006 \\
\hline ZCBS & $\begin{array}{l}\text { Study } \\
\text { Control }\end{array}$ & -0.501 & 0.841 & -0.054 & 0.968 \\
\hline CISS-21-SOC & $\begin{array}{l}\text { Study } \\
\text { Control }\end{array}$ & -0.802 & 0.429 & -2.880 & 0.004 \\
\hline CISS-21-EOC & $\begin{array}{l}\text { Study } \\
\text { Control }\end{array}$ & -1.685 & 0.096 & -3.238 & 0.001 \\
\hline CISS-21-AC & $\begin{array}{l}\text { Study } \\
\text { Control }\end{array}$ & -1.872 & 0.063 & -0.027 & 0.989 \\
\hline BMI-D & $\begin{array}{l}\text { Study } \\
\text { Control }\end{array}$ & -0.122 & 0.904 & -2.615 & 0.009 \\
\hline BMI-DIRD & $\begin{array}{l}\text { Study } \\
\text { Control }\end{array}$ & -1.016 & 0.314 & -1.437 & 0.157 \\
\hline BMI-E & $\begin{array}{l}\text { Study } \\
\text { Control }\end{array}$ & -0.678 & 0.512 & -1.708 & 0.091 \\
\hline EES & $\begin{array}{l}\text { Study } \\
\text { Control }\end{array}$ & -0.976 & 0.341 & -3.186 & 0.001 \\
\hline
\end{tabular}

BDI: Beck Depression Inventory; BAI: Beck Anxiety Inventory; ZCBS: Zarit Care Burden Scale; CISS-21-SOC: The Coping Inventory for Stressful Situations, Solution-oriented Coping; CISS-21-EOC: The Coping Inventory for Stressful SituationsEmotion-oriented Coping; CISS-21-AC: The Coping Inventory for Stressful Situations -Avoidant Coping; BMI-D: Beliefs Toward Mental Illness Scale-Danger; BMI-DIRD: Beliefs Toward Mental Illness Scale- Desperation and Interpersonal Relations Deterioration; BMI-E: Beliefs Toward Mental Illness Scale- Embarrassment; EES: Expressed Emotion Scale

Table 3. Findings Regarding the Difference Between Pre-Test and Post-Test Scores of the Study and Control Groups According to the Scales

\begin{tabular}{lcccc} 
Scales & \multicolumn{2}{c}{ Group } & Study Group & \multicolumn{2}{c}{ Control Group } \\
\hline BDI & -3.924 & 0.000 & Z & 0.292 \\
BAI & -3.747 & 0.000 & -1.054 & 0.985 \\
ZCBS & -0.561 & 0.575 & -0.019 & 0.477 \\
CISS-21-SOC & -3.926 & 0.000 & -0.306 & 0.759 \\
CISS-21-EOC & -3.172 & 0.002 & -0.9555 & 0.339 \\
CISS-21-AC & -2.850 & 0.004 & -1.687 & 0.092 \\
BMI-D & -3.514 & 0.000 & -1.837 & 0.066 \\
BMI-DIRD & -0.499 & 0.618 & -0.819 & 0.413 \\
BMI-E & -2.746 & 0.006 & -0.769 & 0.442 \\
EES & -2.917 & 0.004 & -0.729 & 0.466 \\
\hline
\end{tabular}

BDI: Beck Depression Inventory; BAI: Beck Anxiety Inventory; ZCBS: Zarit Care Burden Scale; CISS-21-SOC: The Coping Inventory for Stressful Situations, Solution-oriented Coping; CISS-21-EOC: The Coping Inventory for Stressful SituationsEmotion-oriented Coping; CISS-21-AC: The Coping Inventory for Stressful Situations -Avoidant Coping; BMI-D: Beliefs Toward Mental Illness Scale-Danger; BMI-DIRD: Beliefs Toward Mental Illness Scale- Desperation and Interpersonal Relations Deterioration; BMI-E: Beliefs Toward Mental Illness Scale- Embarrassment; EES: Expressed Emotion Scale

\section{DISCUSSION}

As well as psychopharmacological treatment in schizophrenia, psychological social approaches are the part of the treatment that affect the course of the disease in a good way (Karon and Vanden Bos 1972, Penn et al. 2005, Dirik et al. 2017, Pharoah et al. 2010). From this point of view, in the present study, the effectiveness of the family mental education program prepared for the relatives of patients with schizophrenia who undertook the burden of a intractable disease and therefore have a taff life was examined. The family psychological training program aimed to provide accurate information about schizophrenia to patients' relatives, to have realistic expectations about the disease and what the patient can do, to reduce relapses by regulating family functio- 
ning, and to reduce stigmatization by increasing the quality of life of both the patient and his / her relatives. Within the scope of the study, data were collected with various self-report scales about depression, anxiety, caregiving burden, coping, beliefs about the disease and emotion expression that were thought to affect the relatives of the patients and the program was found to be effective on the study group. In addition, the control group supported the assumption that this effect is in virtue of the training program. According to the findings of the study, there was no difference between the two groups before the training that both the study and control groups were nearly at the same level in terms of the above-mentioned variables. However, after the family psychological training program there was a significant difference between the two groups, in terms of the depression and anxiety symptoms, coping with solution, emotion-oriented coping, dangerous perception of the disease and expression of emotion but also, there was no significant difference in terms of caregiving burden, avoidant coping, desperation and interpersonal relations deterioration and embarrassment of the disease were detected. While after the given educational programme, the study group decreesed the scores of depression, anxiety, emotion-oriented coping and dangerous perception of the disease, it was observed that the scores of coping with solution and emotion expression increased, in case of the control group any change was not detected. Similarly, when the pre-test and post-test scores of both groups were compared, in the study group a significant and positive change was observed in all sub-dimensions except caregiving burden and desperation and interpersonal relations deterioration, as for that in the control group any change was not detected. According to these results, it was seen that the family mental education program had an effect on the relatives of the patients. It is known that many forms of family intervention are effective in reducing exacerbations in schizophrenia, improving the treatment process and informing the relatives of the patient, developing empathy, providing a non-pathological view of the disease, communication and problem solving skills, even if the effects are different (Glynn et al. 2006, Laskowski \& Lincoln 2021). Many studies in the literature show the effectiveness of mental social programs applied to patients with schizophrenia or their relatives (Tarrier 2005, Baum et al. 2006, He 2008, Ngoc et al. 2016, Ran et al. 2015, Zhou et al. 2020, Al-Sawafi et al. 2020). When conducted studies analyzed in Turkey, it was seen that some training or mental social works are done for some patients with schizophrenia (Özkan et al. 2013, Doğan et al. 2002, Sögütlü et al. 2017) or some works that only made based on the patient's relatives or both the patient and the patient's relatives (Arslantaş et al. 2009, Tel and Terakye 2000, Çetinkaya et al. 2007, Yurtsever et al. 2001, Yu et al. 2020). When these studies were evaluated, it was found that education programs emphasized the existence of a positive change even if it did not result in a significant change. However, the fact that the training program applied did not show a significant difference of the caregiving burden, desperation and interpersonal relations deterioration sub-dimensions at both inter-group and intra-group levels may be due to the social interpretation of the participants about their patients and being influenced of stigma toward to patients with schizophrenia. Another remarkable finding of the study was that almost no change was observed in the emotion expression posttest score in the control group, but it showed a significant decrease in the study group. This situation can also be interpreted as the incapability to manage emotion expressions since the misinterpretation of the feelings of the patients' relatives based on stigma. As it is known stigma does not affect only the patients themselves but also the families of the patients are affected (Corrigan et al. 2006, Guan et al. 2021). However, it may also be possible to reduce the effect of stigma by providing educational support for the mental disorder (Clement et al. 2010, Corrigan and Al-Khouja 2019).

Considering the difficulties of being relatives to the patients, thinking the existence of certain relations the relationships between the variables were analyzed with the first application scores of the whole group. Significant positive correlations were found between depression symptoms and anxiety symptoms, caregiving burden, coping with solution and desperation and interpersonal relationships deterioration. Significant positive correlations were found between anxiety symptoms and caregiving burden and between caregiving burden and avoidant coping, embarrassment of the disease. No significant correlation was found between emotion expression and any scale.

One of the limitations of the study is the small number of samples that are likely to be a group study, therefore making it difficult to generalize the results of the study. However, it is thought that it is possible to talk about a generalizable effect with more educational applications similar to this study. Since more studies will lead to certain evaluations and revisions in the training program, it may also contribute to increasing the effectiveness of the program. This study was conducted with outpatients of patients with schizophrenia in Community Mental Health Center (CMHC). In the current conditions of our country, CMHCs seem to be the most suitable place for such trainings. In addition, the effectiveness of the training program can be tested by following a follow-up study, but this study does not include a follow-up study. These and similar training programs can be applied simultaneously to both patients and their relatives to see if there is an increase in the effect of the study. In addition to the scales used in the study, new researches can be conducted by using other scales particularly the scales that oriented stigma. 


\section{CONCLUSION}

In conclusion, this study shows that mental health education program is effective in patients' relatives with schizophrenia and that reduces depression, anxiety symptoms and dangerous perception of the disease of the patients' relatives, possibly caused by patient care burden, and increases solution-oriented and emotionfocused coping strategies and emotion expression. It has been found that it is beneficial to apply the programs equivalent to the family mental health education program prepared for the relatives of schizophrenia patients. In our opininon, our study is very valuable to meet the neglected needs of psychiatric patients.

\section{Acknowledgements: None.}

\section{Conflict of interest: None to declare.}

\section{Contribution of individual authors:}

Lütfiye Söğütlü: design, data collection and writing up of the paper.

Cenk Varlık: data collection and writing up of the paper.

Ahmet Güler, Yıldız Bilge \& Seyyide Şifa Göktaş: design and writing up of the study.

\section{References}

1. Al-Sawafi A, Lovell K, Renwick L, Husain N: Psychosocial family interventions for relatives of people living with psychotic disorders in the Arab world: systematic review. BMC Psychiatry 2020; 20; 20:413

2. Anderson CM, Reiss DJ, Hogarty GE: Schizophrenia and Family: A practioner's Guide to psychoeducation and management. New York: Guilford Press, 1986

3. Arslantas H, Sevinçok L, Uygur B, Balcı V, Adana F: Impacts of Psychoeducation Among the Caregivers of Schizophrenic Patients to Both Clinical Course of the Illness and to the Level of Expressed Emotion in Caregivers. Meandros Medical And Dental Journal 2009; 10:3-10

4. Bäuml J, Froböse T, Kraemer S, Rentrop M, PitschelWalz G: Psychoeducation: a basic psychotherapeutic intervention for patients with schizophrenia and their families. Schizophrenia bulletin 2006; 32(suppl 1): 1-9

5. Beck AT, Epstein N, Brown, G, Steer, RA: An inventory for measuring clinical anxiety: psychometric properties. Journal of consulting and clinical psychology 1998; 56:893

6. Beck AT, Ward CH, Mendelson M, Mock J, Erbaugh J: An inventory for measuring depression. Archives of general psychiatry 1961; 4(6): 561-571

7. Berksun OE, Soykan Ç, Soykan A: Dlşa vurulan duygulanım ölçeği: ölçek uyarlama üzerine bir pilot çalışma. Türk Psikoloji Dergisi 1993; 8(29):10-15

8. Bilge A, Çam O: Validity and reliability of Beliefs towards Mental Illness Scale. Anadolu Psikiyatri DergistAnatolian Journal Of Psychiatry 2008; 9:91

9. Boysan M: Validity of The Coping Inventory for Stressful Situations - Short Form (CISS-21) in a Non-Clinical
Turkish Sample. Dusunen Adam The Journal of Psychiatry and Neurological Sciences 2012; 2:101-107

10. Bustillo J, Keith SJ, Lauriello J: Schizophrenia: psychosocial treatment. Kaplan and Sadock's Comprehensive Book of Psychiatry, 1210-1217. Philadelphia: Lippincott Williams \& Wilkins, 2000

11. Clement S, Jarrett M, Henderson C, Thornicroft G: Messages to use in population-level campaigns to reduce mental health-related stigma: consensus development study. Epidemiology and Psychiatric Sciences 2010; 19(1):72-79

12. Cole JD, Kazarian SS: The level of expressed emotion scale: a new measure of expressed emotion. Journal of Clinical psychology 1988; 44:392-397

13. Corrigan PW, Watson AC, Miller FE: Blame, shame, and contamination: The impact of mental illness and drug dependence stigma on family members. Journal of family psychology 2006; 20:239

14. Corrigan PW, Al-Khouja MA: Reactions to Solidarity Versus Normalcy Messages for Antistigma Campaigns. J Nerv Ment Dis. 2019; 207:1001-1004

15. Çetinkaya Duman Z, Aștı N, Üçok A, Kuşcu MK: The social and independent living skills, the community reentery program for and follow-up of patients with schizophrenia and their families. Anadolu Psikiyatri Dergisi 2007; 8(2):91-101

16. Dirik A, Sandhu S, Giacco D, Bennison G, Collinson S, Priebe $S$ : Why involve families in acute mental healthcare? A collaborative conceptual review. BMJ Open 2017; 7(9):e017680

17. Dixon L, Adams C, Lucksted A: Update on family psychoeducation for schizophrenia. Schizophrenia Bulletin 2000; 26(1):5-20

18. Doğan S, Doğan O, Tel H, Çoker F, Polatöz Ö, Doğan FB: Psychosocial approaches in outpatients with schizophrenia. Psychiatric Rehabilitation Journal 2004; $27: 279$

19. Dogan S, Dogan O, Tel H, Çoker F, Polatöz Ö, Basegmez FD: Sizofrenide psikososyal yaklasimlar: Ayaktan hastalar1/Psychosocial approaches in schizophrenia: Outpatients. Anadolu Psikiyatri Dergisi 2002; 3(2):69

20. Dogan O, Dogan S, Tel H, Çoker F, Polatöz Ö, Basegmez FD: Sizofrenide psikososyal yaklasimlar: Aileler1/ Psychosocial approaches in schizophrenia: families. Anadolu Psikiyatri Dergisi 2002; 3(3):133

21. Ebrahimi H, Seyedfatemi $N$, Namdar Areshtanab $H$, Ranjbar F, Thornicroft G, Whitehead B, et al.: Barriers to Family Caregivers' Coping With Patients With Severe Mental Illness in Iran. Qual Health Res. 2018; 28(6):987-1001

22. Endler NS, Parker JDA: Assessment of multidimensional coping: Task, emotion, and avoidance strategies. Psychological assessment 1994; 6(1):50

23. Endler NS, Parker JDA: Coping Inventory for Stressful Situations (CISS) Manual. Toronto: Multi-Health System, 1990

24. Esther AA: Coping strategies and depression in caregivers of patients with mental disorders: a casestudy in a tertiary hospital in Nigeria. Nig J Health and Biomed Sci 2003; 2:103-7

25. Fekadu W, Mihiretu A, Craig TKJ, Fekadu A: Multidimensional impact of severe mental illness on family members: systematic review. BMJ Open 2019; 9:e032391 
26. Glynn SM, Cohen AN, Dixon LB, Niv N: The potential impact of the recovery movement on family interventions for schizophrenia: opportunities and obstacles. Schizophrenia Bulletin 2006; 32(3):451-463

27. Guan Z, Wang Y, Lam L, Cross W, Wiley JA, Huang C, et al.: Severity of illness and distress in caregivers of patients with schizophrenia: Do internalized stigma and caregiving burden mediate the relationship? J Adv Nurs. 2021; 77(3):1258-1270

28. Gutiérrez-Maldonado J, Caqueo-Urízar A, Kavanagh $D J$ : Burden of care and general health in families of patients with schizophrenia. Social psychiatry and psychiatric epidemiology 2005; 40(11):899-904

29. Gülseren L, Çam B, Karakoç B, Yiğit T, Danacı AE, Çubukçuoğlu Z, Mete L: The Perceived Burden of Care and its Correlates in Schizophrenia. Turk Psikiyatri Derg 2010; 21:203-212

30. Güleç M, Kalafat T, Boysan M, Barut Y: Psychometric Properties of the Turkish Version of the Posttraumatic Cognitions Inventory (PTCI) in a Non-Clinical Sample. Medical Bulletin of Haseki/Haseki Tip Bulteni 2014; $52(2): 147$

31. He R: Effect of psychoeducation for family members of people with schizophrenia. World Health Dig J New Med 2002; 5.7:1249

32. Heru A, Ryan C: Depressive symptoms and family functioning in the caregivers of recently hospitalized patients with chronic/recurrent mood disorders. International Journal of Psychosocial Rehabilitation 2002; 7:53-60

33. Hirai M, Clum GA: Development, reliability, and validity of the beliefs toward mental illness scale. Journal of psychopathology and Behavioral Assessment 2000; 22(3):221-236

34. Hisli N: Beck depresyon envanterinin universite ogrencileri icin gecerliligi, guvenilirligi.(A reliability and validity study of Beck Depression Inventory in a university student sample). J. Psychol. 1989; 7:3-13

35. Karon BP, VandenBos GR: The consequences of psychotherapy for schizophrenic patients. Psychotherapy: Theory, Research \& Practice 1972; 9(2): 111

36. Kizllırmak B, Küçük L: Care Burden Level and Mental Health Condition of the Families of Individuals With Mental Disorders. Arch Psychiatr Nurs. 2016; 30:47-54

37. Lauber C, Eichenberger A, Luginbühl P, Keller C, Rössler W: Determinants of burden in caregivers of patients with exacerbating schizophrenia. European psychiatry 2003; 18(6):285-289

38. Laskowski A, Lincoln TM: Network meta-analysis on the comparative efficacy of family interventions for psychotic disorders: a protocol. BMJ Open. 2021; 20;11(1):e039777

39. National Mental Health Project Working Group; 2005

40. Magliano L, Fiorillo A, DeRosa C, Malangone C, Maj M: Family burden in long-term diseases: A comparative study in schizophrenia vs. physical disorders. Social Science \& Medicine 2005; 61(2): 313-322

41. Mokwena KE, Ngoveni A: Challenges of Providing Home Care for a Family Member with Serious Chronic Mental Illness: A Qualitative Enquiry. Int J Environ Res Public Health. 2020; 17(22):8440

42. Mueser KT, Glynn SM: Behavioral family therapy for psychiatric disorders (2nd ed.). Oakland, CA: New Harbinger, 1999
43. Murray CJ, Lopez A: The global burden of disease. Harvard School of Public Health. Harvard University Press 1996; 1:201-46

44. Ngoc TN, Weiss B, Trung LT: Effects of the family schizophrenia psychoeducation program for individuals with recent onset schizophrenia in Viet Nam. Asian journal of psychiatry 2016; 22:162-166

45. Özkan B, Erdem E, Demirel Özsoy S, Zararsiz G: The effects of psychoeducation and telepsychiatric follow-up on social functioning and medication adherence in the patients with schizophrenia. Anatolian Journal of Psychiatry 2013; 14(3):191-199

46. Özlü A, Yıldız M, Aker T: A Reliability and Validity Study on the Zarit Caregiver Burden Scale. Archives of Neuropsychiatry 2009; 46 Supplement: 38-42

47. Penn DL, Waldheter EJ, Perkins DO, Mueser KT, Lieberman JA: Psychosocial treatment for firstepisode psychosis: a research update. Am J Psychiatry 2010; 162:2220-2220

48. Pharoah F, Mari J, Rathbone J, Wong W: Family intervention for schizophrenia. Cochrane Database Syst Rev. 2010; (12):CD000088

49. Rahmani F, Ranjbar F, Hosseinzadeh M, Razavi SS, Dickens GL, Vahidi M: Coping strategies of family caregivers of patients with schizophrenia in Iran: A cross-sectional survey. Int J Nurs Sci. 2019; 6(2):148153

50. Ran MS, Chan CW, Ng SM, Guo LT, Xiang MZ; The effectiveness of psychoeducational family intervention for patients with schizophrenia in a 14-year follow-up study in a Chinese rural area. Psychological medicine 2015; 45(10):2197-2204

51. Sağduyu A, Aker T, Özmen E, Uğuz Ş, Ögel K, Tamar D: Relatives' beliefs and attitudes towards schizophrenia: An epidemiological investigation. Turk Psikiyatri Derg 2003; 14(3):203-212

52. Shah AJ, Wadoo O, Latoo J: Psychological distress in carers of people with mental disorders. British Journal of Medical Practitioners 2010; 3(3):a327

53. Söğ̈̈tlü L, Özen Ş, Varlık C, Güler A: Toplum ruh sağlığl merkezinde şizofreni hastalarına ruhsal toplumsal beceri eğitimi uygulanması ve sonuçları Anadolu Psikiyatri Derg. 2017; 18:121-128

54. Stengard E: Educational intervention for the relatives of schizophrenia patients in Finland. Nord $J$ Psychiatr 2003; 57:271-277

55. Tarrier N: Cognitive behaviour therapy for schizophrenia - a review of development, evidence and implementation. Psychotherapy and Psychosomatics 2005; 74:136-144

56. Tel H, Terakye G: The effects of psychoeducatinal approach for the handling of disease symptoms and coping with stress among relatives of schizophrenic patients. Anadolu Psikiyatri Dergisi 2000; 1(3):133

57. Ulusoy M, Sahin NH, Erkmen H: The Beck anxiety inventory: psychometric properties. Journal of cognitive psychotherapy 1998; 12(2):163-172

58. Vos T, Allen C, Arora M, Barber RM, Bhutta ZA, Brown $A$, Coggeshall M: Global, regional, and national incidence, prevalence, and years lived with disability for 310 diseases and injuries, 1990-2015: a systematic analysis for the Global Burden of Disease Study 2015. The Lancet 2016; 388(10053):1545-1602 
59. World HealthOrganization (WHO). Newsroom/ Factsheets/ Detail/Schizophrenia, 2018. https://www.who.int/ newsroom/fact-sheets/detail/schizophrenia (date of access: 12.09.2019)

60. Yıldız M: Kocaeli Ünv. Tıp Fakültesi Psikiyatri ABD psikiyatrik rehabilitasyon birimi gündüz hastanesi uygulamasl: bir ilk deneme değerlendirmesi. Psikiyatrik Rehabilitasyon Bülteni 2005; 1:1-19

61. Yıldız M: Psikiyatrik Rehabilitasyonun Felsefesi. 3P Dergisi 2000; 8(4):11-15

62. Yu W, Chen J, Hu J, Hu J: Relationship between Mental Health and Burden among Primary Caregivers of Outpatients with Schizophrenia. Fam Process. 2019; 58(2):370-383

63. Yu Y, Li T, Xi S, Li Y, Xiao X, Yang M, et al.: Assessing a WeChat-Based Integrative Family Intervention (WIFI) for Schizophrenia: Protocol for a Stepped-Wedge Cluster Randomized Trial. JMIR Res Protoc 2020; 25;9(8):e18538

64. Yurtsever ÜE, Kutlar T, Tarlacı N, Kamberyan K, Yaman M: Ruh hastalıklarl tedavisinde psikososyal bir boyut: Psikoeğitimsel bir model. Dusunen Adam The Journal of Psychiatry and Neurological Sciences 2001; 1(14):33-40

65. Zarit SH, Reever KE, Bach-Peterson J: Relatives of the impaired elderly: correlates of feelings of burden. The gerontologist 1980; 20:649-655

66. Zhou DR, Chiu YM, Lo TW, Lo WA, Wong SS, Luk KL, et al.: Outside-in or Inside-out? A Randomized Controlled Trial of Two Empowerment Approaches for Family Caregivers of People with Schizophrenia. Issues Ment Health Nurs. 2020; 41:761-772

Correspondence:

Assistant Proffessor Lütfiye Söğütlü, MD

Department of Psychology, University of Health Sciences

Istanbul, Turkey

E-mail: lutfiyeulgeli@hotmail.com 